Revista de la red interuniversitaria de estudios sobre las literaturas rioplatenses contemporáneas en Francia

19 | 2018

La rebelión de los hijos: el judaísmo en la literatura latinoamericana contemporánea entre tradición y asimilación

\title{
Qué clase de judío soy
}

\section{Daniel Samoilovich}

\section{(2) OpenEdition}

Journals

Edición electrónica

URL: http://journals.openedition.org/lirico/6688

DOI: $10.4000 /$ lirico.6688

ISSN: 2262-8339

Editor

Réseau interuniversitaire d'étude des littératures contemporaines du Río de la Plata

Referencia electrónica

Daniel Samoilovich, "Qué clase de judío soy », Cuadernos LIRICO [En línea], 19 | 2018, Puesto en línea el 11 diciembre 2018, consultado el 21 abril 2019. URL : http://journals.openedition.org/lirico/6688 ; DOI : 10.4000/lirico.6688

Este documento fue generado automáticamente el 21 abril 2019.

\section{c) (i) (8)}

Cuadernos LIRICO está distribuido bajo una Licencia Creative Commons Atribución-NoComercial-

SinDerivar 4.0 Internacional. 


\title{
Qué clase de judío soy
}

\author{
Daniel Samoilovich
}

Una vez, un joven dirigente de una asociación comunitaria, me preguntó: “¿Qué clase de judío sos vos? No distinguís Kippur de Rosh Hashaná, no crees en Dios, no celebrás la llegada del sábado... ni siquiera sabés idish..." Apenas atiné a contestarle que estoy circunciso, lo cuál no sé si le habrá bastado. Evidentemente, de las señales de pertenencia que enumeró, la de mínima era, a su entender, saber idish. Lo cierto es que me gustaría: me parece un idioma lleno de energía, adivino que es tan eficaz para el humor como para la maldición, para la felicidad y la melancolía... se me ocurre que ha de ser espléndido para la poesía, tanto como, digamos, el portugués, idioma de marineros y comerciantes... quizás mejor... Pero el hecho es que si fuera posible graduar mis ignorancias, soy más ignorante del idish que del portugués. Mi padre si sabía, y lo hablaba con sus padres y sus hermanos, pero no con mi madre, que es mizrahi, o sea descendiente de la minoría de judíos que, cuando los demás partieron a la diáspora, quedó en Palestina y la región.

El idish era entonces el idioma de mis abuelos paternos, y su sonido venía mezclado con la casa en donde vivían, baja, pobre, y enorme comparada con la mía; una casa con una terraza donde mi abuelo, un hombretón que había sido herrero, se entretenía haciendo erráticos arreglos y, si no había nada que arreglar, desarmando cajones de fruta para rescatar y enderezar los clavos. Venía el idish mezclado con las disputas de aquel anciano alto y mi abuela pequeñita, de la que se decía que un día en Ucrania había escondido de una requisa de la policía a cuarenta personas y un revólver: o sea, una aldea completa en el sótano de su casa.

A mí lo de los cuarenta prófugos se me mezclaba con la historia de Ali Babá y los cuarenta ladrones; no entendía bien como cabría tanta gente en el sótano, ni para qué querían un revólver, que los incriminaba y con el cual mal podrían defenderse de la policía del zar. También se decía que una vez que un pollo se había desventrado la abuela lo había agarrado, le había metido las tripas para adentro y tranquilamente lo había cosido y de un modo igualmente tranquilo el pollo había salido caminando. La sal de la historia -que yo encontraba de algún modo equivalente a la de los cuarenta escondidos- era la calma de la abuela y el pollo, y esa era, a mi pequeña mente racionalista, justamente la parte más dudosa. Pero nunca se me hubiera ocurrido expresar tales dudas; las historias me gustaban así, y aún me gustan: mis abuelos habían vivido una gran aventura, venían desde muy lejos en el espacio y el tiempo, desde territorios que no necesitaban detalles ni explicaciones. Que hablaran una lengua especial, a la que se llamaba idish o jargon (la jerga) era lógico, viniendo, como venían, de otro planeta. 
Era, claro, el mismo planeta donde transcurrían las historias de los libros. Yo tenía diez, once años y leía todo lo que me caía a la mano, desde los libros de Verne o Salgari que me daban hasta los de Pearl S. Buck o Romain Rolland, que no me daban y manoteaba yo de la biblioteca de mis padres. Así que cuando la abuela se enfermó, me encargaron que por las tarde fuera a leerle cuentos y novelas. Ella hablaba, como dije, idish, ruso y, después de cuarenta años aún con acento, castellano, pero era analfabeta en cualquier lengua. Después he pensado que es raro haberle leído cuentos a la abuela, en lugar de que ella me los leyera a mí: la lengua aparece así desprovista de gravedad, desprovista del peso de la tradición. Quizás algo de mi deseo de escribir, o de las modalidades que ese deseo fue tomando, tengan que ver con aquel paisaje dado vuelta. 0 tal vez aquella ausencia de espesor de la nueva lengua alentó en mí una irresponsabilidad, una prepotencia sin la cual difícilmente hubiera sido escritor.

Una vez empecé a leerle Miguel Strogoff, la historia del correo que debe recorrer miles de verstas a lo largo de Siberia para llevarle al zar un mensaje de su hermano asediado por una rebelión. No creo que hayamos elegido ese libro por su tema ruso, porque leíamos de todo... pero puede que la casualidad nos hubiera llevado a aquel escenario y que, aunque Rusia es tan vasta que Strogoff lo más cerca que ha de estar de Ucrania en su carrera deben ser tres o cuatro mil kilómetros, todo aquello de los kirguises, los tártaros, la policía zarista, tuviera para ella algún punto de interés especial... En cuanto a mí, estaba convencido de que le estaba contando la historia de unos parientes cercanos: aquellos kanes rebeldes en cualquier momento podían ponerse a hablar en idish, y entonces sería ella la que me explicara qué decían...

Kafka piensa que unir la propia voz a la de otros es estar ya perdido, y empero sueña a menudo con ser "plenamente judío": se fascina con los actores del teatro idish, y aún quisiera compartir el destino de los míseros emigrantes del Este que ve en una barraca esperando el permiso para partir a América. Pertenencia, identidad, son para él a veces imagen de la salvación, a veces de la condena. Si bien se piensa, se podría decir lo mismo de la soledad: también ella es para él, alternativamente, salvación y condena. Uno se pregunta entonces si no es esta, finalmente, la condición natural del escritor. Ser "plenamente" parte de un colectivo quizás resolvería muchas angustias... pero junto con el agua sucia, es muy posible que se fuera también el niño. 